IRA-International Journal of Management \& Social Sciences

ISSN 2455-2267; Vol.05, Issue 01 (2016)

Pg. no. 194-202

Institute of Research Advances

http://research-advances.org/index.php/RAJMSS

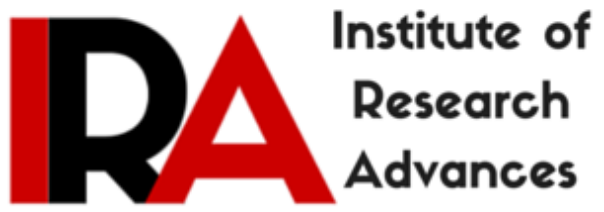

\title{
Contribution of SHRM towards Organizational Effectiveness- A Study with Reference to NGOs in Kerala
}

\author{
Anu P. Mathew \\ Assistant Professor, Department of Commerce, Deva Matha College \\ Kuravilangad, Kerala, India.
}

Type of Review: Peer Reviewed.

DOI: http://dx.doi.org/10.21013/jmss.v5.n1.p19

How to cite this paper:

Mathew, A. (2016). Contribution of SHRM towards Organizational Effectiveness- A Study with Reference to NGOs in Kerala. IRA-International Journal of Management \& Social Sciences (ISSN 2455-2267), 5(1), 194-202. doi:http://dx.doi.org/10.21013/jmss.v5.n1.p19

(C) Institute of Research Advances

(cc) EY-NC

This work is licensed under a Creative Commons Attribution-Non Commercial 4.0 International License subject to proper citation to the publication source of the work.

Disclaimer: The scholarly papers as reviewed and published by the Institute of Research Advances (IRA) are the views and opinions of their respective authors and are not the views or opinions of the IRA. The IRA disclaims of any harm or loss caused due to the published content to any party. 


\begin{abstract}
As the business environment has become more and more complex and uncertain over the years, it becomes imperative for organizations to adopt strategies and effectively putting them into practice so that they can attain solid competitive advantage in the fiercely competitive market. Human resources very well play a significant part in realization of organizational goals in the most effective manner. Effective alignment of firm's strategies with the individual ones is the end result of successful Strategic Human Resource Management. This is even more relevant with NGOs as their vital resource is not material or infrastructure oriented but rather human oriented. The more is the linkage between HRM and organizational performance through strategic means the greater will be the organizational outcome. Through this research paper, a study is being made to understand how significantly related is SHRM and organizational effectiveness. Data collected through primary and secondary sources validate a highly positive relationship between the both.
\end{abstract}

Key Words: Employee/ Organizational Performance, HR Outcomes, Operational Outcomes, Organizational Climate, Reward System, SHRM

\title{
Introduction
}

NGOs nationally and internationally indeed have a crucial role in helping and encouraging Governments to take up programmes ensuring holistic economic development. Many NGOs have demonstrated an ability to reach poor people, work in inaccessible areas, innovate or achieve results in a much better way than that by government agencies. They complement the development efforts of the Governments and helps in making the development process more accountable, transparent and participatory. They not only fill the gaps but also act as a worthy solution to failures in Public and Private sector basic service delivery models.

NGOs fall into various categories such as Service NGOs, Participatory NGOs, Charity NGOs and Empowering NGOs based on their orientation which in turn drives their performance. For instance, The Kerala State Women's Development Corporation (KSWDC) seeks to bring women out of binding normative strictures by making them active participators in societal development and progress. It fulfills the Government of Kerala's concern in empowering the women of the State. On one side, demand for their services is rising, owing to the slow pace of poverty reduction and a backlog of social deprivation. On the other, the NGOs face tough internal challenges, from weak leadership to organizational irrelevance, from inadequate funding to an inability to market themselves to their target audience.

\section{Origin of the Problem}

Business environment is changing rapidly and this change is evident in the economic, political, legal, social and technological surroundings by way of such phenomena as the globalization, liberalization, changing customer and investor demands, ever-increasing product-market competition, need for technological upgradations and maintaining a proper work- life balance. In order to create and sustain competitive advantage in this type of environment, organizations must continually improve their business performance. Increasingly, organizations are recognizing the potential of their human resources as a source of sustained competitive advantage. The people who make up an organization -human resources- are considered to be one of the most important resources of today's firms. What is necessitated is to understand why success through human resources can be long lasting and cannot be easily imitated by competitors. (Caliskan, 2010)

The performance of NGOs can be improved tremendously if they realize that in today's complex world, professional management expertise is essential to get the best out of the employees for the betterment of the organization. Effective employee management should be on the top of the list of 
priorities for progressive improvement of an organization. An NGO must strive to attract, develop and retain qualified and enthusiastic employees as they are the key to the success of one's business. NGOs have an ever increasing need to attract the right people to the right positions in a constantly evolving environment. Heads of NGOs and those long associated with the development sector will confirm that the supply of well qualified people, prepared to make necessary sacrifices in respect of remuneration, for the sake of the cause, has diminished over the years. Job opportunities for today's educated youth are more widespread. This has made a career in development domain far less attractive to people in that age group from which the sector drew its strengths from in 1970s and 1980s. NGOs now have a high demand for skilled employees to help the organization function at its best.

It is at this juncture the role of Strategic Human Resource Management (SHRM) holds significance. SHRM refers to the management of human resources of an organization in accordance with the intentions of the organization focusing on the future direction it wants to take. Importance of human factor cannot be denied in achieving vision of the NGOs. NGO managers need to know the strategies to increase employee commitment, retention and work-life balance in NGOs so that such issues of employees are addressed properly to foster optimum utilization of human resources within the organization.

Hence, this research paper was intended to explore the contribution of Strategic Human Resource Management towards better organizational performance in the context of operational NGOs in Kerala to learn how competent human resources in NGOs are and how are they managed effectively for the comprehensive development of the NGOs and hence the study is titled Contribution of SHRM towards Organizational Effectiveness- A Study with Reference to NGOs in Kerala.

\section{Objectives}

1. To analyze how SHRM practices have influenced performance of NGOs in Kerala.

2. To understand how SHRM influences the organizational climate within the NGOs in Kerala.

\section{Methodology}

The main aim of the study was to gain insights into the impact of Strategic Human Resource Management on Organizational Effectiveness. With the help of a Structured Interview Schedule, relevant data was collected from NGOs functioning across the State of Kerala. The researcher collected data from a total of 200 employees of 12 NGOs belonging to the Northern, southern and Central parts of Kerala. Required data was also assembled from research papers, conference/ working papers, books and journals. The analysis of the responses and literature support the effectiveness of SHRM as a driving force behind organizational effectiveness and success.

\section{Research Discussions}

The analysis of the research insights regarding the way SHRM influences the Organizational performance are studied in relation to variables such as Employee/ Organizational Performance, Reward System and Organizational Climate.

\section{Employee/ Organizational Performance}

The next construct under the research design to arrive at reflections on Strategic Human Resource Management with regard to Operational NGOs is Employee/Organizational Performance. Once the Talent Management function is being properly executed, the next focus is on the way and how far that has shaped into effective employee and organizational performance. For this two main variables have been identified as HR Outcomes and Operational Outcomes. First we shall deal with HR outcomes: 
(a) H R Outcomes

Respondents' opinion regarding HR outcomes of the SHRM practices being implemented in their respective organization with regard to Employee Performance was collected on a five point scale. The intention was to know how well they agree with the impact of SHRM on the work force.

The frequencies of opinion of respondents regarding HR Outcomes arrived at NGOs have been found and the general frequency of such opinions was arrived at by considering the following criteria;

$$
\begin{gathered}
\text { Mean score } 1 \text { to } 1.80=\text { Fully Disagree } \\
1.80 \text { to } 2.60=\text { Disagree } \\
2.60 \text { to } 3.40=\text { Neutral } \\
3.40 \text { to } 4.20=\text { Agree } \\
4.20 \text { to5.00 }=\text { Fully Agree }
\end{gathered}
$$

Table 1: HR Outcomes

\begin{tabular}{|l|c|c|c|c|c|c|}
\hline \multicolumn{1}{|c|}{ (a) H R Outcomes } & $\begin{array}{c}\text { Fully } \\
\text { Agree }\end{array}$ & Agree & Neutral & Disagree & $\begin{array}{c}\text { Fully } \\
\text { Disagree }\end{array}$ & Mean \\
\hline Increased Job Satisfaction & 88 & 106 & 6 & & & 4.41 \\
\hline Employee Motivation \& Morale & 120 & 66 & 14 & & & 4.53 \\
\hline Enhanced Employee Loyalty & 93 & 87 & 20 & & & 4.365 \\
\hline Enhanced Communication & 132 & 68 & & & & 4.66 \\
\hline Strengthened Work Relationships & 122 & 72 & 6 & & & 4.52 \\
\hline Employee Skills \& Abilities & 114 & 68 & 18 & & & 4.48 \\
\hline Employee Empowerment & 139 & 61 & & & & 4.695 \\
\hline Minimized Labour Turnover & 95 & 100 & 5 & & & 4.45 \\
\hline Reduced Absenteeism & 140 & 50 & 10 & & & 4.65 \\
\hline Reduced Job Stress & 117 & 78 & 5 & & & 4.56 \\
\hline Relieved from Work Overload & 93 & 103 & 4 & & & 4.445 \\
\hline Improved Employee Efficiency & 121 & 79 & & & & 4.605 \\
\hline
\end{tabular}

The above Table proves that the employees experience the HR Outcomes to be positive and favourable as they have expressed Full agreement with the statements given recording a high mean score in the category of 4.20 to 5.00 representing Fully Agree.

Among the HR Outcomes, the highest rated ones are for facilitating employee empowerment (mean=4.695), enhancing communication between managers and employees (mean=4.66), reducing absenteeism (mean=4.65), improving employee efficiency (mean=4.605), reducing job stress (mean=4.56) promoting employee motivation and morale (mean=4.53) and strengthening relationships at work $(\mathrm{mean}=4.52)$. They do agree fully with outcomes in the organizations such as encouraging employee skills and abilities, improving employee efficiency, minimizing labour turnover, relieving from workload, increased job satisfaction and enhanced employee loyalty.

The success and efficacy of any initiative is gauged from the valid results it brings forth. In that way, SHRM practices in operational NGOs is highly commendable as they have succeeded in generating positive outcomes with regard to their human resources.

\section{(b) Operational Outcomes}

Respondents' opinion regarding Operational outcomes of the SHRM practices being implemented in their respective organization with regard to Organizational Performance was collected on a five point scale. The intention was to know how well they agree with the impact of SHRM on the organizational performance. 
The frequencies of opinion of respondents regarding Operational Outcomes arrived at NGOs have been found and the general frequency of such opinions was arrived at by considering the already mentioned criteria.

Table 2: Operational Outcomes

\begin{tabular}{|l|c|c|c|c|c|c|}
\hline \multicolumn{1}{|c|}{ (a) Operational Outcomes } & $\begin{array}{c}\text { Fully } \\
\text { Agree }\end{array}$ & Agree & Neutral & Disagree & $\begin{array}{c}\text { Fully } \\
\text { Disagree }\end{array}$ & Mean \\
\hline Improved Quality of Output & 139 & 61 & & & & 4.695 \\
\hline Enhanced Productivity & 132 & 64 & 4 & & & 4.64 \\
\hline Economy of Operations & 94 & 64 & 42 & & & 4.26 \\
\hline Better Stakeholder Relationships & 93 & 71 & 36 & & & 4.285 \\
\hline More Business; More Profit & 140 & 56 & 4 & & & 4.68 \\
\hline $\begin{array}{l}\text { Organizational Effectiveness through } \\
\text { TQM }\end{array}$ & 132 & 60 & 8 & & & 4.62 \\
\hline
\end{tabular}

The analysis reveals the existence of a strong SHRM system in the NGOs under study as the operational outcomes carry a very positive role much to the strength of the organization. Being asked their view points on the operational outcomes that SHRM caters to, they opined full agreement with all the given statements marking a mean score of 4.20 to 5.00. According to them, SHRM results in more business and thereby more profit (mean=4.68), improved quality of output (mean=4.695), enhanced productivity (mean=4.64) and organizational effectiveness through TQM (mean=4.62). They fully agree with operational outcomes of better stakeholder relationships and economy of operations too.

The analysis validates that the contribution of SHRM is truly significant as far as the operational NGOs in Kerala are concerned. It can be understood from the feedbacks of the employees regarding the results SHRM was able to attain such as fetching more business and improvement in the quality of output produced.

\title{
2. Reward System
}

The next construct under the research design to arrive at reflections on Strategic Human Resource Management with regard to Operational NGOs is Reward System. The effectiveness of the first two constructs such as Talent Management and Employee/Organizational Performance depends to a great extent on the successful implementation of the Reward System being maintained in the organization. Hence the respondents' reaction towards the Reward System they are part of was studied on a five point scale asking them to express their level of agreement towards a few statements. The purpose was to understand how satisfied they are with the present reward system. The frequencies of opinion of respondents regarding HR Outcomes arrived at NGOs have been found and the general frequency of such opinions was arrived at by considering the following criteria;

\author{
Mean score 1 to $1.80=$ Fully Disagree \\ 1.80 to $2.60=$ Disagree \\ 2.60 to $3.40=$ Neutral \\ 3.40 to $4.20=$ Agree \\ 4.20 to5.00=Fully Agree
}


Table 3: Reward System

\begin{tabular}{|l|c|c|c|c|c|c|}
\hline \multicolumn{1}{|c|}{ Opinion } & $\begin{array}{c}\text { Fully } \\
\text { Agree }\end{array}$ & Agree & Neutral & Disagree & $\begin{array}{c}\text { Fully } \\
\text { Disagree }\end{array}$ & Mean \\
\hline Reasonable Reward System & 60 & 96 & 29 & 5 & 10 & 3.955 \\
\hline Satisfactory Monetary Benefits & 64 & 56 & 43 & 20 & 17 & 3.65 \\
\hline Adequate Incentives & 40 & 58 & 31 & 52 & 19 & 3.24 \\
\hline Necessary Welfare Measures & 95 & 93 & 12 & 0 & 0 & 4.415 \\
\hline Performance Related Benefits & 94 & 34 & 43 & 12 & 17 & 3.88 \\
\hline Proper Security Measures & 185 & 15 & 0 & 0 & 0 & 4.925 \\
\hline Potential for Growth \& Development & 116 & 72 & 12 & 0 & 0 & 4.52 \\
\hline
\end{tabular}

The results depict a fairly good position with regard to the Reward system being implemented by operational NGOs in Kerala as with three statements, respondents have opined Full agreement, while they have agreed with three of them and were neutral with a statement. They thoroughly agree with being ensured of proper security measures (mean=4.925), and fully agree that there is potential for growth and development for employees $($ mean=4.52) and that they are provided with necessary welfare measures $(m e a n=4.415)$. They agree that reward system existing in the organization is reasonable (mean=3.995), performance related benefits are being offered (mean=3.88) and monetary benefits being provided are satisfactory $(\mathrm{mean}=3.65)$. The respondents believe they are deprived of adequate incentives (mean=3.24) as they have been neutral to that statement.

All together the employees are not dissatisfied with the way their monetary needs are being taken care of by their respective organizations as they agree with the practicality of the prevailing reward system and satisfaction towards the system.

\title{
3. Organizational Climate
}

The final construct under the research design to arrive at reflections on Strategic Human Resource Management with regard to Operational NGOs is Organizational Climate. Akin to the construct, Reward System, this aspect also assumes importance in determining the success of Talent Management operations and Organizational and Employee Performance outcomes.

Hence the respondents' opinion regarding the Organizational Climate they are provided with was studied on a three point scale asking them to express their level of agreement towards a few statements. The purpose was to understand how they perceive the Organizational Climate to which they confronted with.

The frequencies of opinion of respondents through regarding Organizational Climate prevailing in NGOs have been found and the general frequency of such opinions was arrived at by considering the following criteria;

\author{
Mean score 1 to $1.7=$ To No Extent \\ 1.7 to $2.4=$ To Some Extent \\ 2.4 to $3=$ To a Great Extent
}


Table 4: Organizational Climate

\begin{tabular}{|l|c|c|c|c|}
\hline \multicolumn{1}{|c|}{ Opinion } & $\begin{array}{c}\text { To a } \\
\text { Great } \\
\text { Extent }\end{array}$ & $\begin{array}{c}\text { To Some } \\
\text { Extent }\end{array}$ & $\begin{array}{c}\text { To No } \\
\text { Extent }\end{array}$ & Mean \\
\hline Interpersonal Conflicts among Employees & 9 & 65 & 136 & 1.456 \\
\hline Role Conflicts & 16 & 53 & 131 & 1.425 \\
\hline Job Stress/ Work Overload & 14 & 64 & 122 & 1.46 \\
\hline Conflict between Management \& Employees & 24 & 38 & 138 & 1.43 \\
\hline Work Life Imbalance & 19 & 50 & 131 & 1.44 \\
\hline Employee Involvement in Decision Making & 94 & 88 & 18 & 2.38 \\
\hline $\begin{array}{l}\text { Grievance Redressal Measures/ Suggestion } \\
\text { Schemes }\end{array}$ & 115 & 70 & 15 & 2.5 \\
\hline
\end{tabular}

Among the seven statements, five were negative statement and two were positive ones. Hence for the negatives ones, low mean score falling in the category 1 to 1.70 indicating To No Extent is desirable. As it is shown in the Table the Organizational Climate existing in the operational NGOs in Kerala is in a highly favourable condition as there the traces of conflicts and stress as well as work life imbalance is minimal.

Opinion on Role conflicts (mean $=1.425)$, conflict between management and employees $($ mean $=1.43)$ and Interpersonal Conflicts among Employees (mean $=1.456)$ indicate that conflicts exist to no extent. Work life imbalance $($ mean $=1.44)$ and Job Stress/ Work Overload $($ mean $=1.46)$ are also recorded at a lower note with the lowest mean category of to no extent. While employee involvement in decision making prevails to some extent $($ mean $=2.38)$, respondents opined that Grievance redressal measures/ suggestion schemes $($ mean $=2.55)$ are being properly functioning in their respective organizations.

\section{Findings}

The key findings in relation to research objectives are outlined below:

(a) HR Outcomes

It was found that the experience of employees with the HR Outcomes is positive and favourable as they have expressed Full agreement with the statements in the Schedule. Among the $H R$ Outcomes, the highest rated ones are for facilitating employee empowerment (mean=4.695), enhancing communication between managers and employees (mean=4.66), reducing absenteeism (mean=4.65), improving employee efficiency (mean=4.605), reducing job stress (mean=4.56) promoting employee motivation and morale $($ mean $=4.53)$ and strengthening relationships at work (mean=4.52).

(b) Operational Outcomes

From the response of the employees, it was found that the operational outcomes carry a very positive role much to the strength of the organization. According to them, SHRM results in more business and thereby more profit (mean=4.68), improved quality of output (mean=4.695), enhanced productivity (mean=4.64) and organizational effectiveness through TQM (mean=4.62). They fully agree with operational outcomes of better stakeholder relationships and economy of operations too. 


\section{(c) Reward System}

The results of analysis depict a fairly good position with regard to the Reward system being implemented by operational NGOs in Kerala. The respondents thoroughly agree with being ensured of proper security measures (mean=4.925), and fully agree that there is potential for growth and development for employees $($ mean=4.52) and that they are provided with necessary welfare measures (mean=4.415). They agree that reward system existing in the organization is reasonable $($ mean=3.995), performance related benefits are being offered (mean=3.88) and monetary benefits being provided are satisfactory (mean=3.65). The respondents believe they are deprived of adequate incentives (mean=3.24) as they have been neutral to that statement.

(d) Organizational Climate

The Organizational Climate existing in the operational NGOs in Kerala is found to be in a highly favourable condition as there the traces of conflicts and stress as well as work life imbalance is minimal. Opinion on Role conflicts (mean $=1.425$ ), conflict between management and employees $($ mean $=1.43)$ and Interpersonal Conflicts among Employees $($ mean $=1.456)$ indicate that conflicts exist to no extent. Work life imbalance $($ mean $=1.44)$ and Job Stress/ Work Overload $($ mean $=1.46)$ also exist to no extent. While employee involvement in decision making prevails to some extent $($ mean $=2.38)$, Grievance redressal measures/ suggestion schemes $($ mean $=2.55)$ exist in NGOs to a great extent.

\section{Conclusion}

Organizational efficiency is the end product of effective utilization of all the organizational resources out of which contribution from the part of Human resources is the most prominent one determining successful culmination of organizational activities. Human resources are depositories of knowledge, skills and talents that can redefine the operational efficiency of the organization they are part of. Hence framing far sighted strategies for effective management of Human resources gathers significance. An organization with a healthy organizational climate coupled with satisfactory reward system and proactive management strategies are sure to bring better individual and organizational outcomes.

\section{References}

1. Arler, H., Janet (2012). Strategic Human Resource Management in Context: A Historical and Global Perspective. Academy of Management Perspectives, May, p. 6-11.

2. Caliskan Nemli Esra (2010). The Impact of Strategic Human Resource Management on Organizational Performance. Journal of Naval Science and Engineering, Vol.6, No.2, pp 100116, retrieved from www.dho.edu.tr

3. Hamid Jery (2013). Strategic Human Resource Management and Performance: The Universalistic Approach- Case of Tunisia. Journal of Business Studies Quarterly, Volume 5, No.2, Retrieved from www.jbsq.org

4. Huselid, A. Mark et.al; (1997). Technical and Strategic Human Resource Management Effectiveness as Determinants of Firm Performance. The Academy of Management Journal, Vol.40, No.1, pp. 171-188, retrieved from www.jstor.org

5. Legnick- Hall, L., Mark (2009). Strategic Human Resource Management: The Evolution of the Field. Human Resource Management Review, Vol.19, pp 64-85, retrieved from www.elsevier.com

6. Michael Armstrong (2006). Strategic Human Resource Management: A Guide to Action. Kogan Page. London. p. 77-78.Retrieved from www.koganpage.com

7. Mitchell Rebecca et.al; (2013). The Effect of Strategic Human Resource Management on Organizational Performance: The Mediating Role of High Performance Human Resource Practices. Human Resource Management, Vol.52, No. 6, pp 899-921, retrieved from onlinelibrary.wiley.com 
8. Wei Li-Qun \& Lau Chung-Ming (2008). The Impact of Market Orientation and Strategic HRM on Firm Performance: The Case of Chinese Enterprises. Journal of International Business Studies, Vol.39, No.6, pp 980-995 retrieved from Palgrave Macmillan Journals www.jstor.org 